\title{
Photocatalytic Production of Hydrogen: an Innovative Use for Biomass Derivatives
}

\author{
Marcos de Oliveira Melo ${ }^{a}$ and Luciana Almeida Silva ${ }^{*, a, b}$ \\ ${ }^{a}$ Instituto de Química and ${ }^{b}$ Instituto Nacional de Ciência e Tecnologia - INCT em Energia e \\ Ambiente, Universidade Federal da Bahia, Campus de Ondina, 40170-290 Salvador-BA, Brazil
}

\begin{abstract}
Hidrogênio é considerado o vetor energético do futuro por ser não poluente e muito flexível quanto à conversão a diferentes formas de energia, como calor por combustão ou energia elétrica via células a combustível. Tradicionalmente, o hidrogênio é produzido a partir da reforma a vapor de gás natural de origem fóssil, o que torna a implantação efetiva da economia de hidrogênio insustentável do ponto de vista ambiental. Para contornar esse problema, diversas rotas de produção de hidrogênio a partir de fontes renováveis estão sendo propostas. Pesquisas recentes apontam a reforma foto-induzida de biomassa como uma possibilidade promissora, uma vez que utiliza radiação solar, fonte inesgotável de energia e matérias primas renováveis como derivados de biomassa e água. Os trabalhos nesse campo são ainda muito incipientes, porém bastante animadores. O processo consiste na combinação da decomposição fotocatalítica da água com a reação de fotodecomposição de substâncias orgânicas mediadas por um semicondutor irradiado. Neste processo, a reação de oxidação da água é suprimida pela presença de um doador de elétrons de sacrifício (biomassa), assim como a formação de radical superóxido quando a reação é realizada em condições anaeróbicas. Os resultados de reforma foto-induzida apontam para rendimentos semelhantes ou superiores a outros processos de produção de hidrogênio a partir de biomassa como hidrólise enzimática e reforma catalítica em fase aquosa. No entanto, os trabalhos desenvolvidos até o momento estão focados no $\mathrm{TiO}_{2}$, o que limita a porção absorvida da radiação solar à luz UV. Deste modo, o grande desafio atual nesta área é o desenvolvimento de semicondutores de banda estreita capazes de conduzir a reação de reforma foto-induzida de biomassa com luz visível, que consiste de cerca de $40 \%$ da radiação solar.
\end{abstract}

Hydrogen is considered the energy carrier of the future because of its clean and very flexible conversion into different forms of energy, e.g., into heat via combustion or electricity via fuel cells. Traditionally, hydrogen is produced from natural gas steam reforming from fossil fuels making the effective implementation of hydrogen economically and environmentally unsustainable. To overcome this problem, several routes are being proposed for hydrogen production from renewable sources. Recent research points to the photoinduced reforming of biomass as a promising possibility, since it uses solar radiation, an inexhaustible source of energy, and raw materials derived from renewable sources such as biomass and water. Studies in this field are still incipient but quite encouraging. The process combines photocatalytic water splitting with the photodecomposition of organic compounds mediated by an irradiated semiconductor. In this process, the water oxidation reaction is suppressed by a sacrificial electron donor (biomass), as well as the formation of superoxide radicals when the reaction is carried out under anaerobic conditions. The hydrogen production rates from photoinduced reforming are similar or superior to other processes, including biomass hydrolysis and aqueous phase reforming. However, the major researches into hydrogen production by photoinduced reforming of biomass derivatives have focused on $\mathrm{TiO}_{2}$, which limits the portion of solar radiation absorbed as UV light. Thus, the current challenge in this field is the development of narrow band gap semiconductors that are able to drive the photoinduced reform of biomass with visible light, which corresponds to about $43 \%$ of solar radiation.

Keywords: photoinduced reforming, biomass, hydrogen, sunlight, photocatalysis

*e-mail: las@ufba.br 


\section{Introduction}

Energy is a fundamental element of productivity, as important as raw materials, capital and labor. The discovery and use of new fuels with higher energy content have seen a corresponding increase in the advance of technology and worldwide population growth. A variety of renewable energy sources exist. Certain methods of biomass utilization are environmentally friendly and renewable, such as biomass fermentation to produce hydrogen, and fuels, such as soy methyl ester (soybean-derived biodiesel), can be used in conventional diesel vehicles. Biomass contributes about $12 \%$ to the world current energy supply. Interest in the use of renewable fuel began with the direct use of vegetable oils as a substitute for diesel. However, the direct use of vegetable oils in diesel engines involves numerous problems, ${ }^{1,2}$ like lower power output and thermal efficiency of the engine, oil ring sticking, thickening or gelling of the lubricating oil as result of contamination by vegetable oils and others. Other disadvantages of vegetable oils and especially animal fats are their high viscosity ( $c a$. 11-17 times higher than diesel fuel) and lower volatility, which cause carbon to deposit in engines due to incomplete combustion. Several chemical or physical modifications aimed at overcoming these drawbacks have been tested, including pyrolysis, microemulsification, dilution and transesterification. Among these methods, transesterification (the most viable process known so far to reduce viscosity when operating at low temperatures and pressures) has a high conversion efficiency of $98 \%$. However, in theory, one mole of glycerol accompanied by three moles of biodiesel can be produced, which means that about $10 \mathrm{~kg}$ of glycerol are produced per $100 \mathrm{~kg}$ of biodiesel.

Glycerol is a high energy density alcohol. ${ }^{3}$ This nontoxic, nonvolatile, nonflammable and highly versatile chemical has more than 1,500 different uses documented since $1945 .{ }^{4}$ High purity glycerol is an important industrial feedstock for applications in the food, cosmetics, pharmaceutical and other industries. Almost two thirds of the industrial uses of this glycerol are in food and beverage (23\%), personal care $(24 \%)$, oral care $(16 \%)$ and tobacco $(12 \%){ }^{4}$ However, the cost of refining crude glycerol is high, especially for medium-sized and small manufacturers. Therefore, to prevent the value of crude glycerol from collapsing, many researchers have focused on innovative uses for this compound. One promising possibility is to use glycerol as a renewable source of hydrogen, which is often defined as the future energy vector. Also, herbaceous and woody energy crops, industrial, agricultural and aquatic crops, crop and animal waste, forest residues and waste, and industrial and municipal wastes can be used for the production of hydrogen by thermochemical and biological processes. $^{5}$

Hydrogen is a storable, clean and environmentally friendly fuel whose combustion results in the solely generation of water, with no emissions of atmospheric pollutants, greenhouse gases or particulates. However, about 95\% of hydrogen currently derives from fossil fuels, mainly by steam reforming of natural gas and petroleum, while the remaining $5 \%$ comes from the electrolysis of water. Because this process involves the use of nonrenewable resources or high energy consumption, this form of hydrogen production is not sustainable or economically feasible. Over the last few years, biomass, mainly glycerol, has been used to produce hydrogen by different methods, such as steam reforming, ${ }^{6}$ gasification, ${ }^{7}$ autothermal reforming, ${ }^{8}$ aqueous-phase reforming, ${ }^{9}$ electrochemical reforming, ${ }_{10}^{10}$ photofermentation ${ }^{11}$ and supercritical water reforming ${ }^{12}$ processes. Most of the studies on hydrogen production from biomass have focused on thermochemical routes. Adhikari et al. ${ }^{13}$ made a thermodynamic analysis of steam reforming of glycerol for hydrogen production. Based on their findings, they concluded that the best conditions for producing hydrogen are at a temperature higher than $627^{\circ} \mathrm{C}$, under atmospheric pressure. However, hydrogen can be produced from biomass in ambient conditions (temperature and pressure) via a photocatalytic route, an efficient, ecologically benign and low-cost process. This technology is based on photoelectrochemical cells operating with two redox systems: one reacting with the holes at the surface of the semiconductor electrode and the second reacting with the electrons entering the counterelectrode. In photocatalytic hydrogen production, the biomass derivative is oxidized to carbon dioxide and water at the semiconductor photoanode and water is reduced to hydrogen at the cathode. In this article, we review the hydrogen production process using an aqueous solution of biomass derivatives via a semiconductor-mediated photocatalytic process.

\section{Semiconductor Photocatalysis}

Semiconductors are characterized by a full valence band and an empty conduction band. When a semiconductor is irradiated by light with energy matching or greater than its band gap energy, $\mathrm{E}_{\mathrm{g}}$, an electron is promoted from the valence band, $\mathrm{VB}$, to the conduction band, $\mathrm{CB}$, leaving a hole behind. The valence band holes $\left(h_{V B}^{+}\right)$are powerful oxidants, while the conduction band electrons $\left(e_{C B}^{-}\right)$ are good reductants. Due to their electronic structures, semiconductors can act as mediators in redox processes according to the following general mechanism, with the 
characteristic times for each step: ${ }^{14}$

Step I: Semiconductor $+h v\left(>\mathrm{E}_{\mathrm{g}}\right) \rightarrow e_{C B}^{-}+h_{V B}^{+}(\mathrm{fs})(1)$

Step II: $e_{C B}^{-}+h_{V B}^{+} \rightarrow$ heat $\quad(10-100 \mathrm{~ns})$

Step III: $\mathrm{Ox}+e_{C B}^{-} \rightarrow \mathrm{Ox}^{-} \quad$ (ms)

Step IV: Red $+h_{V B}^{+} \rightarrow \operatorname{Red}^{+} \quad(100 \mathrm{~ns})$

Step V: $\mathrm{Red}^{+} \rightarrow \rightarrow \rightarrow \mathrm{CO}_{2}, \mathrm{Cl}^{-}, \mathrm{H}^{+}, \mathrm{H}_{2} \mathrm{O}$

The first step (I) in the photoelectrochemical mechanism ${ }^{14,15}$ is the formation of charge carriers by a photon, as illustrated in Figure 1. These excited charge carriers are mobile and capable of initiating several chemical redox reactions (III and IV) at the semiconductor surface. The excited electrons and holes in the absence of suitable electron and hole scavengers (Ox and Red species in the mechanism) tend to recombine quickly, dissipating the energy as heat within a few nanoseconds (II). On the other hand, the interfacial electron transfer in reduction reactions is very slow, on a scale of milliseconds. Therefore, the photocatalytic activity of semiconductors is largely

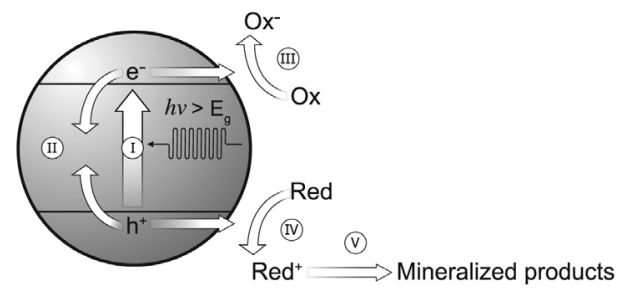

Figure 1. Primary steps in the photoelectrochemical mechanism: (I) formation of charge carriers $\left(h_{V B}^{+}\right.$and $e_{C B}^{-}$) after photon absorption; (II) recombination of charge carriers with release of heat; (III) adsorption of species reduced by photogenerated electrons; (IV) initiation of an oxidative pathway by photogenerated holes; (V) further thermal and photocatalytic reactions to yield mineralization products. dependent on the competition between the surface transfer of charge carriers and the electron-hole recombination. If a suitable scavenger or surface defect is available to trap the electron or hole, recombination is prevented and further thermal and photocatalytic reactions may occur to yield mineralization products $(\mathrm{V})$.

The width of the band gap is a measure of the strength of the chemical bond. ${ }^{16-21}$ Semiconductors that are stable under illumination, typically metal oxides, usually consist of the top of the valence band located at $+3 \mathrm{~V}$ or higher ( $v s$. NHE), with a major contribution of $2 p$ orbitals from oxygen atoms. Therefore, if the bottom of the conduction band of a given metal oxide is located at a more negative potential than the hydrogen reduction potential $\left(\mathrm{E}^{\circ}=0 \mathrm{~V} v s\right.$. NHE at $\mathrm{pH} 0$ ), the band gap of the material becomes larger than $3 \mathrm{eV}(1 \mathrm{eV}$ is the energy of an electron with an electrical potential of $1 \mathrm{~V}$ ), yielding a wide band gap semiconductor whose absorption edge tends towards the ultraviolet, putting it outside the visible spectrum. From the standpoint of solar energy, the development of photocatalysts, which can drive redox reactions under visible light $(\lambda>400 \mathrm{~nm})$, is indispensable. Figure 2 shows the band positions of several semiconductors in contact with aqueous solution at $\mathrm{pH} 1$ and their band gap energies.

The lower edge of the conduction band and upper edge of the valence band are presented along with the band gap in electron volts. To achieve a redox reaction, the bottoms of the conduction bands must be located at a more negative potential than the reduction potential of the chemical species that will be reduced, while the tops of the valence bands must be positioned more positively than the oxidation potential of the chemical species that

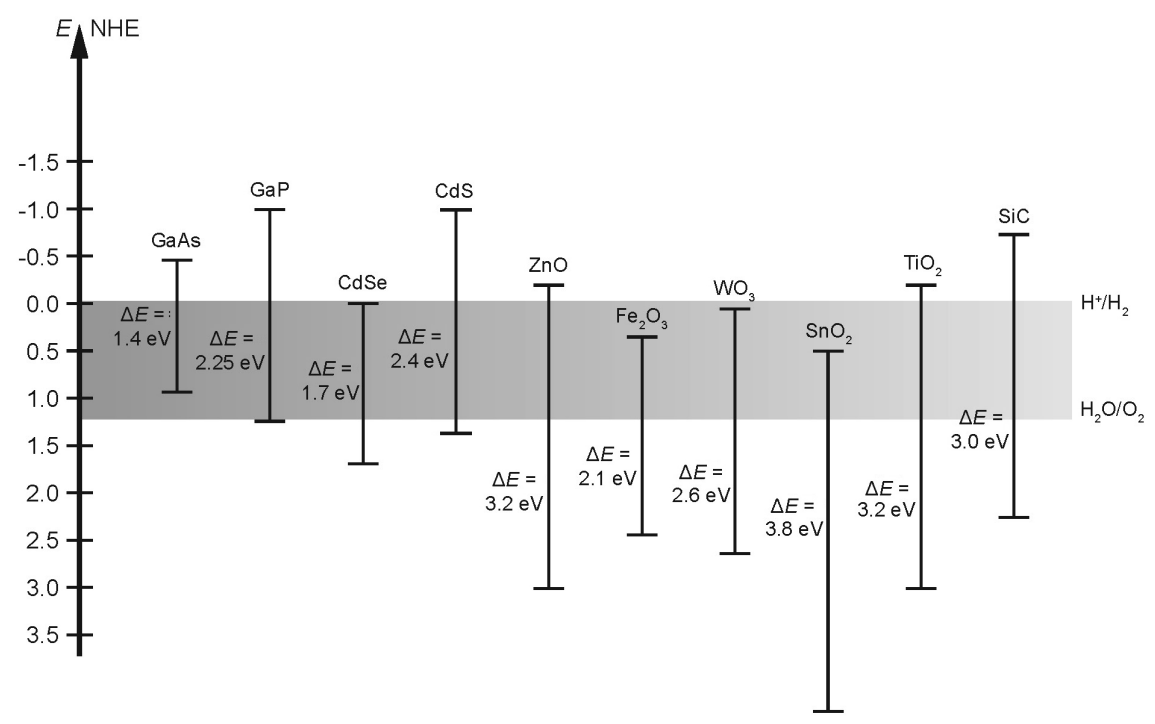

Figure 2. Band positions of several semiconductors in contact with aqueous solution at pH 1 and their band gap energies. The energy scale is indicated in electron volts using the normal hydrogen electrode (NHE). 


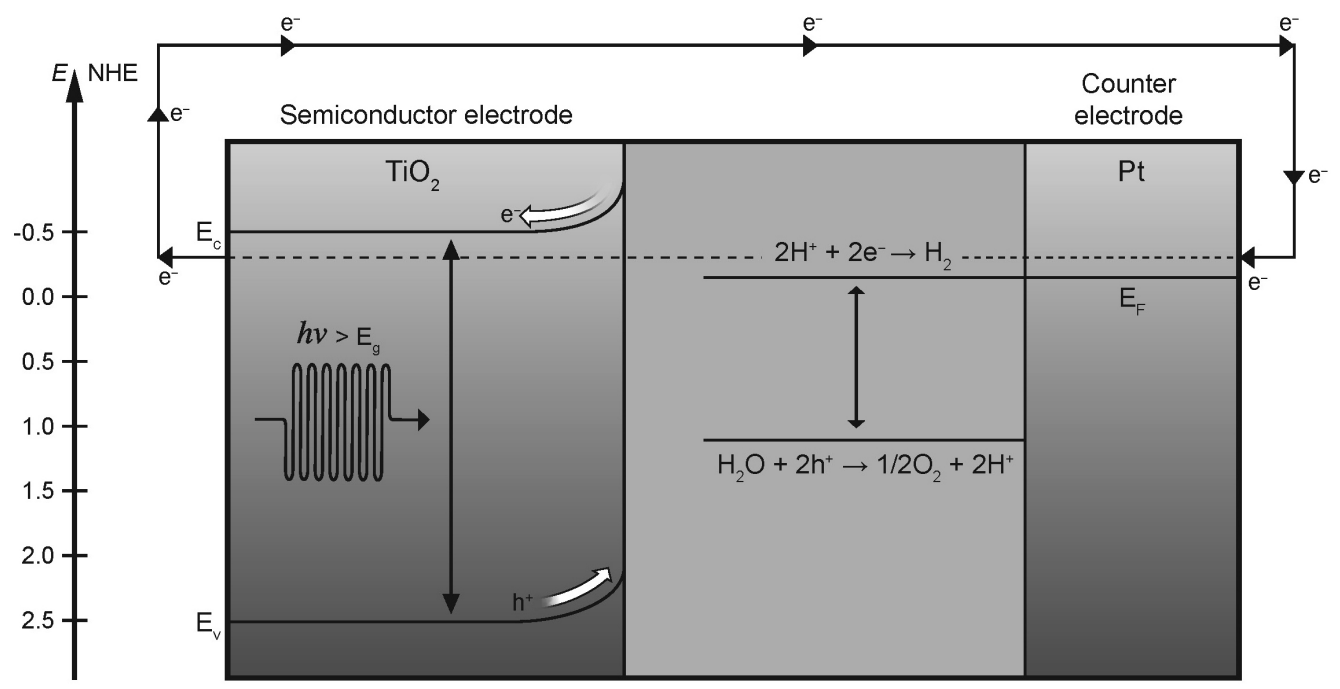

Figure 3. Principle of operation of a photoelectrochemical cell that generates hydrogen through the photocleavage of water.

will be oxidized. Therefore, the minimum photon energy required to drive such a reaction thermodynamically is the difference between the energies of the top of the valence band and the bottom of the conduction band.

\section{Photocatalytic Water Splitting}

Artificial photosynthesis is a dream that involves capturing the freely available energy from sunlight and turning it into a valuable and strategic fuel such as hydrogen. Photoelectrochemistry provides a way to mimic photosynthesis by employing a semiconductor electrode to absorb and utilize solar energy to convert chemicals into other forms.

The photoelectrolysis of water was first carried out with a system in which an n-type $\mathrm{TiO}_{2}$ semiconductor (rutile) electrode ${ }^{22-24}$ connected by an electrical charge to a black platinum counter electrode was exposed to near-UV light $(<400 \mathrm{~nm})$. When the surface of the $\mathrm{TiO}_{2}$ electrode was illuminated, electrons flowed from it to the platinum counter electrode through the external circuit. As Figure 3 illustrates, the direction of the current indicates that an oxidation reaction (oxygen gas evolution) occurs at the $\mathrm{TiO}_{2}$ electrode and a reduction reaction (hydrogen gas evolution) occurs at the Pt electrode.

The principle of water photoelectrolysis guided the design of particulate systems for photocatalytic water splitting. $\mathrm{A} \mathrm{TiO}_{2}$ particle with a small amount of $\mathrm{Pt}$ deposited on it is essentially a miniature photoelectrochemical cell on which water is oxidized at the naked oxide and is reduced at the Pt-covered area to achieve the desired overall reaction (Figure 4). When a metal is deposited on a semiconductor, excited electrons from the semiconductor migrate to the metal until the two Fermi levels are aligned. The

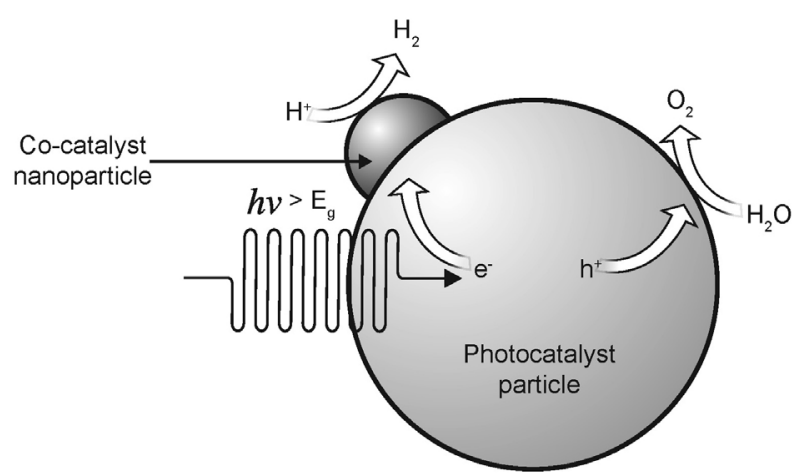

Figure 4. Schematic representation of the photocatalytic water splitting on a platinized semiconductor powder particle.

Schottky barrier ${ }^{25,26}$ formed at the metal and semiconductor interface can serve as an efficient electron trap to prevent photogenerated electron-hole recombination, which greatly enhances the efficiency of the photocatalytic reaction. At the same time, the metal is important because of its own catalytic activity. The metals deposited on a semiconductor serve as an active site for $\mathrm{H}_{2}$ production, in which the trapped photogenerated electrons are transferred to protons to produce $\mathrm{H}_{2}$. Thus, the photocatalytic activity is strongly dependent on the metal charge.

To achieve overall water splitting, the bottom of the conduction band of the semiconductor must be located at a more negative potential than the reduction potential of $\mathrm{H}^{+}$to $\mathrm{H}_{2}\left(\mathrm{E}^{\circ}=0 \mathrm{~V}\right.$ vs. NHE at $\left.\mathrm{pH} 0\right)$, while the top of the valence band must be more positively positioned than the oxidation potential of $\mathrm{H}_{2} \mathrm{O}$ to $\mathrm{O}_{2}\left(\mathrm{E}^{\circ}=1.23 \mathrm{~V} v s\right.$. NHE) (see Figure 2). The overall reaction is quite unfavorable $\left(\Delta \mathrm{G}^{\circ}=+238 \mathrm{~kJ} \mathrm{~mol}^{-1}\right)$. However, with the input of light energies at wavelengths $\leq 1,000 \mathrm{~nm}$ (i.e., $1.23 \mathrm{eV} \approx$ $1000 \mathrm{~nm}$ photon), the overall energy required for the photosynthetic splitting of water can be readily provided 
by solar radiation. This fact shows that, using UV-Visible light, water can be decomposed into oxygen and hydrogen without the application of an external voltage, according to the following equations:

Semiconductor $+h v(<1,000 \mathrm{~nm}) \rightarrow e_{C B}^{-}+h_{V B}^{+}$

$\mathrm{H}_{2} \mathrm{O}+2 h_{V B}^{+} \rightarrow 1 / 2 \mathrm{O}_{2}+2 \mathrm{H}^{+}$(at semiconductor surface)

$$
\mathrm{E}^{\mathrm{o}}=1.23 \mathrm{~V}
$$

$2 \mathrm{H}^{+}+2 e_{C B}^{-} \rightarrow \mathrm{H}_{2}$ (at Pt nanoparticle) $\quad \mathrm{E}^{\mathrm{o}}=0 \mathrm{~V}$

The overall reaction is:

$\mathrm{H}_{2} \mathrm{O}+h v(<1,000 \mathrm{~nm}) \rightarrow \mathrm{H}_{2}+1 / 2 \mathrm{O}_{2} \quad \mathrm{E}^{\mathrm{o}}=-1.23 \mathrm{~V}$

Hydrogen ions reduced by photogenerated electrons come from the hydrolysis reaction on the metal oxide surface suspended in water, e.g., in $\mathrm{TiO}_{2}$, the hydrolyzed surface sites are the "titanol" moiety, > TiOH. Hydroxyl groups on the $\mathrm{TiO}_{2}$ surface are known to undergo the following acid-base equilibria: ${ }^{14}$

$>\mathrm{TiOH}_{2}^{+} \rightleftharpoons>\mathrm{TiOH}+\mathrm{H}^{+}$

$>\mathrm{TiOH} \rightleftharpoons>\mathrm{TiO}^{-}+\mathrm{H}^{+}$

\section{Photoinduced Reformation of Biomass}

Semiconductor-mediated photocatalytic processes have been widely investigated in recent years as potentially efficient, economic and environmentally friendly methods for a wide range of industrial applications, including mineralization of organic pollutants and disinfection of water and air. ${ }^{22,27-31}$ Many works ${ }^{26,32-37}$ have shown that the photocatalytic degradation of organic compounds, such as azo dyes, proteins, alcohols, sugars, and organic acids, under non-aerated conditions takes place with the simultaneous production of hydrogen over irradiated semiconductor photocatalyst suspensions or immobilized films. Other strange sources of organic compounds have been investigated since the 1980s. Kawai et al., ${ }^{37}$ for example, demonstrated the feasibility of producing photocatalytic hydrogen from decomposing algae, dead insects, and excrement on $\mathrm{TiO}_{2}$ photocatalysts with only the $\mathrm{CO}_{2}$ by-product in the gaseous phase.

The photocatalytic splitting of water to produce $\mathrm{H}_{2}$ and $\mathrm{O}_{2}$ in sunlight is an "up-hill" reaction. The production of hydrogen and oxygen from water cleavage takes place in non-aerated conditions and is achieved by photogenerated electrons and holes, respectively, provided that they have sufficient energy to reduce protons toward hydrogen molecules and to oxidize water toward oxygen (discussed in section 3 ). On the other hand, the complete oxidation of organic compounds into $\mathrm{CO}_{2}$ and $\mathrm{H}_{2} \mathrm{O}$ under aerated conditions is classified as a "down-hill" reaction, accompanied by a large negative change in the Gibbs energy $(\Delta G<0)$. The photocatalytic oxidation of organic compounds takes place in the presence of oxygen with the participation of photogenerated holes, which act either directly or indirectly via the generation of hydroxyl radicals ( $\mathrm{HO}^{*}$ ), finally leading to the production of $\mathrm{CO}_{2}$ and $\mathrm{H}_{2} \mathrm{O}$. In the case of $\mathrm{TiO}_{2}$, the redox potential for photogenerated holes is $+2.53 \mathrm{~V} v s$. the normal hydrogen electrode (NHE) in aqueous solution at $\mathrm{pH}$ 7. After their reaction with water, these holes can produce hydroxyl radicals (HO'), as indicated by equation 12 .

$\begin{array}{lll}\mathrm{H}_{2} \mathrm{O}+h_{V B}^{+} \rightarrow \mathrm{HO}^{\circ}+\mathrm{H}^{+} & \mathrm{E}^{\mathrm{o}}=+2.27 \mathrm{~V}(\mathrm{pH} 7) \\ \mathrm{O}_{2}+e_{C B}^{-} \rightarrow \mathrm{O}_{2}^{-\cdot} & \mathrm{E}^{\mathrm{o}}=-0.28 \mathrm{~V}(\mathrm{pH} \mathrm{7}) \\ \mathrm{O}_{2}+2 e_{C B}^{-}+2 \mathrm{H}^{+} \rightarrow \mathrm{H}_{2} \mathrm{O}_{2} & \mathrm{E}^{\mathrm{o}}=+0.28 \mathrm{~V}(\mathrm{pH} 7) \\ 2 \mathrm{H}_{2} \mathrm{O}+2 h_{V B}^{+} \rightarrow \mathrm{H}_{2} \mathrm{O}_{2}+2 \mathrm{H}^{+} & \mathrm{E}^{\mathrm{o}}=+1.35 \mathrm{~V}(\mathrm{pH} 7)\end{array}$

Photogenerated electrons are consumed by chemisorbed oxygen to form superoxide radicals $\left(\mathrm{O}_{2}^{-\cdot}\right)$ (equation 13). As a consequence of the two-electron reduction of oxygen, $\mathrm{H}_{2} \mathrm{O}_{2}$ can also be formed, as can be seen in equation 14 . Due to the redox potentials of the electron-hole pair, $\mathrm{H}_{2} \mathrm{O}_{2}$ can theoretically be formed via another pathway in an aqueous solution (equation 15). Hydrogen peroxide may also contribute to the degradation of organic and inorganic electron donors by acting as a direct electron acceptor or as a direct source of hydroxyl radicals due to homolytic scission. ${ }^{13}$

In certain biomass compounds, the standard Gibbs energy for the reforming reaction is positive $\left(\right.$ e.g., $\Delta \mathrm{G}^{\mathrm{o}}=4 \mathrm{~kJ} \mathrm{~mol}^{-1}$ for glycerol reforming and $\Delta \mathrm{G}^{\mathrm{o}}=97 \mathrm{~kJ} \mathrm{~mol}^{-1}$ for ethanol reforming), but these reactions can be induced by photons, similarly to the water splitting reaction. The proposed photoreforming process combines the water splitting and oxidation reactions of organic compounds. The photocatalytic treatment of aqueous solutions of biomass components and derivatives (denoted as $\mathrm{C}_{\mathrm{x}} \mathrm{H}_{\mathrm{y}} \mathrm{O}_{\mathrm{z}}$ ) takes place under non-aerated conditions in a photocatalytic cell, whose design is summarized in Figure 5. This results in the oxidation of the organic substrate by holes initiated by reactions represented by equations 12 and 15, toward $\mathrm{CO}_{2}$ (step IV in Figure 5), which is accompanied by the production of gas-phase hydrogen from water (step I in Figure 5), represented by equation 8. While step II, represented by equation 7 , and step III, represented by equations 13 and 14, are suppressed.

Therefore, Kondarides et al..$^{38}$ combined the reactions of steps I and IV in a photocatalytic cell, using $\mathrm{Pt} / \mathrm{TiO}_{2}$ as the photocatalyst under UV light irradiation (Figure 5). 


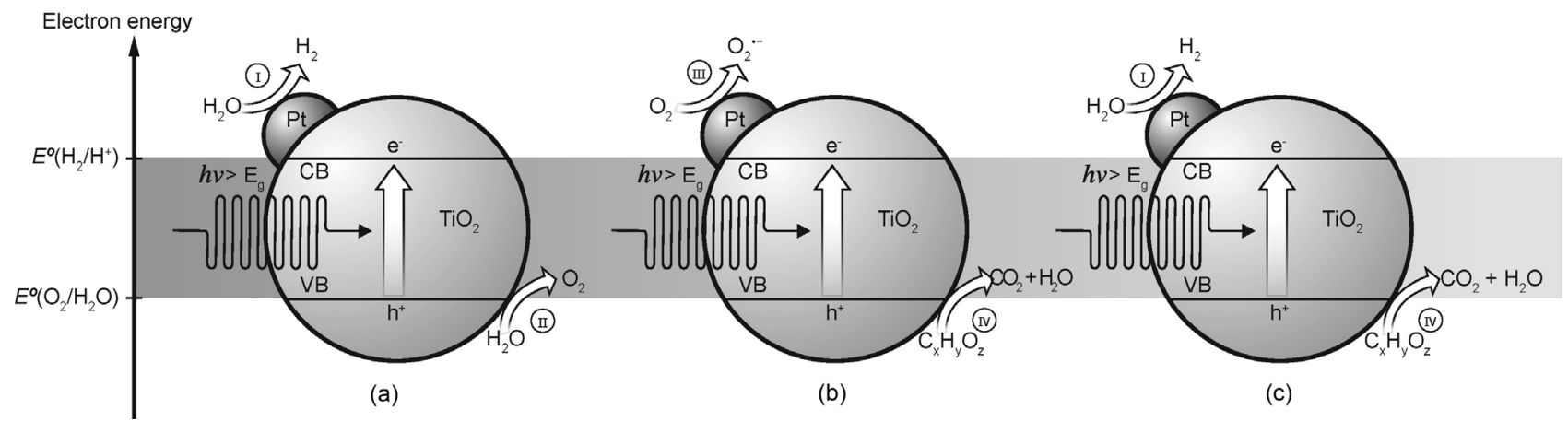

Figure 5. Schematic representation of photocatalytic reactions: (a) water splitting; (b) biomass oxidation; (c) photoinduced reforming of biomass.

The authors showed that hydrogen can generally be produced in an efficient process via the photocatalytic reforming of biomass components and derivatives in ambient conditions.

A large variety of biomass-derived components was tested by Kondarides et al. ${ }^{38}$ including monosaccharides, such as pentoses (ribose, arabinose) and hexoses (glucose, calactose, fructose, and mannose), alcohols (methanol, ethanol, propanol, and butanol) and organic acids (acetic acid, formic acid). In all cases, the amounts of $\mathrm{H}_{2}$ and $\mathrm{CO}_{2}$ produced were found to be in accordance to the stoichiometry of the following general reforming reaction:

$$
\mathrm{C}_{\mathrm{x}} \mathrm{H}_{\mathrm{y}} \mathrm{O}_{\mathrm{z}}+(2 \mathrm{x}-\mathrm{z}) \mathrm{H}_{2} \mathrm{O} \rightarrow \mathrm{xCO}_{2}+(2 \mathrm{x}-\mathrm{z}+\mathrm{y} / 2) \mathrm{H}_{2}
$$

Fu et al. ${ }^{26}$ reported a systematic study of hydrogen production by anaerobic photocatalytic reforming of glucose on noble-metal loaded $\mathrm{TiO}_{2}$ photocatalyst under UV light irradiation. The authors made an in-depth investigation of the effects of the reaction atmosphere, the type of noble metal loaded on $\mathrm{TiO}_{2}$, the amount of loaded platinum, the crystalline structure of $\mathrm{TiO}_{2}$, the initial concentration of glucose and the solution's $\mathrm{pH}$ on the evolution of hydrogen. They concluded that all these parameters can affect the hydrogen evolution rate, specially the kind and concentration of noble-metal loads $(\mathrm{Ru} \approx \mathrm{Ag}<\mathrm{Rh} \approx \mathrm{Au}<\mathrm{Pt}<\mathrm{Pd})$ and the initial $\mathrm{pH}$ of the solution, which reaches a maximum hydrogen evolution at $\mathrm{pH}$ 11. A mechanism based on three processes was proposed for glucose (denoted as $\mathrm{RCH}_{2} \mathrm{OH}$ and $\mathrm{R}^{\prime} \mathrm{CH}_{2} \mathrm{OH}$ ) photo-oxidation:

$$
\begin{aligned}
& \text { Process (a): } \\
& \mathrm{RCH}_{2} \mathrm{OH} \rightarrow \mathrm{H}^{+}+\mathrm{RCH}_{2} \mathrm{O}^{-} \\
& \mathrm{RCH}_{2} \mathrm{O}^{-}+h_{V B}^{+} \rightarrow \mathrm{RCH}_{2} \mathrm{O}^{-} \\
& \mathrm{RCH}_{2} \mathrm{O}^{-}+\mathrm{R}^{\prime} \mathrm{CH}_{2} \mathrm{OH} \rightarrow \mathrm{RCH}_{2} \mathrm{OH}+\mathrm{R}^{\prime} \dot{\mathrm{C}} \mathrm{HOH}
\end{aligned}
$$

Process (b):

$$
\mathrm{R}^{\prime} \dot{\mathrm{C}} \mathrm{HOH}+h_{v B}^{+} \rightarrow \mathrm{H}^{+}+\mathrm{R}^{\prime} \dot{\mathrm{C}} \mathrm{HO} \bullet \rightarrow \mathrm{R}^{\prime} \mathrm{CHO}
$$

Process (c):

$$
\begin{aligned}
& \mathrm{R}^{\prime} \mathrm{CHO}+\mathrm{HO} \rightarrow\left[\mathrm{R}^{\prime} \mathrm{COOH}\right]^{-}+\mathrm{H}^{+} \\
& {\left[\mathrm{R}^{\prime} \mathrm{COOH}\right]^{-}+h_{V B}^{+} \rightarrow \mathrm{R} \mathrm{H}+\mathrm{CO}_{2}}
\end{aligned}
$$

Overall reaction:

$$
\mathrm{C}_{6} \mathrm{H}_{12} \mathrm{O}_{6}+6 \mathrm{H}_{2} \mathrm{O} \rightarrow 6 \mathrm{CO}_{2}+12 \mathrm{H}_{2}
$$

However, the authors ${ }^{26}$ themselves concede that the true mechanism must be more complex and that it requires a determination and analysis of the intermediates.

Wu et al. ${ }^{39}$ also studied the production of $\mathrm{H}_{2}$ from the photocatalytic reformation of glucose on metal/ $\mathrm{TiO}_{2}$ photocatalyst, focusing special attention on the selectivity of $\mathrm{CO}$, which easily poisons noble metal-based catalysts even at ultralow concentrations. Wu et al. ${ }^{39}$ who also found that the $\mathrm{H}_{2}$ production rate depends on the type of deposited metal, reported that $\mathrm{H}_{2}$ production increases in the following order: $\mathrm{Ir}<\mathrm{Ru}<\mathrm{Au}<\mathrm{Ni} \approx \mathrm{Cu} \approx \mathrm{Pt}<\mathrm{Rh}$. Moreover, the lowest concentration of $\mathrm{CO}$ in $\mathrm{H}_{2}$ is in the $\mathrm{Rh} / \mathrm{TiO}_{2}$ photocatalyst.

Although the growing worldwide demand for biodiesel has generated a huge amount of glycerol as by-product, few studies have focused on the photocatalytic reforming of this biomass derivative. A recent work published by Daskalaki et al. ${ }^{40}$ investigated photocatalytic reforming of glycerol using a $\mathrm{Pt} / \mathrm{TiO}_{2}$ photocatalyst under UV light irradiation. Their results show that hydrogen can be produced efficiently by photocatalytic reforming of aqueous solutions of glycerol, which eventually results in a complete conversion of glycerol to $\mathrm{H}_{2}$ and $\mathrm{CO}_{2}$. Optimal results were reported for $\mathrm{TiO}_{2}$ photocatalyst loaded with 0.1-0.5 wt. \% Pt, whereas a further increase of platinum content had a detrimental effect on the photocatalytic performance. The reaction was more favorable with neutral and basic solutions than with acidic solutions, and the reaction rate increased substantially when the temperature increased from 40 to $60-80{ }^{\circ} \mathrm{C}$. At high glycerol concentrations (ca. $1 \mathrm{~mol} \mathrm{~L}^{-1}$ ), the hydrogen evolution rate was about two orders of magnitude higher than that obtained with pure water, making the process suitable for application. 
Table 1. Hydrogen evolution rates obtained by photoinduced reforming using an UV solar light-simulating source, and comparison with other procedures

\begin{tabular}{|c|c|c|c|c|}
\hline Route & Biomass & Catalyst & $\begin{array}{l}\mathrm{H}_{2} \text { production / } \\
\left(\mu \mathrm{mol} \mathrm{g}_{\text {cat }}{ }^{-1} \mathrm{~h}^{-1}\right)\end{array}$ & Ref \\
\hline Photocatalysis & glycerol & 0.5 wt. $\% \mathrm{Pt} / \mathrm{TiO}_{2}$ & $3.5 \times 10^{2}$ & 38 \\
\hline Photocatalysis & glycerol & $0.5 \mathrm{wt} . \% \mathrm{Pt} / \mathrm{TiO}_{2}$ & $\begin{array}{c}4.35 \times 10^{2} \\
\left(\mathrm{pH} 11 \text { at } 60^{\circ} \mathrm{C}\right)\end{array}$ & 40 \\
\hline Photocatalysis & glycerol & 2.0 wt. $\%(\mathrm{~B}, \mathrm{~N})$-codoped $\mathrm{TiO}_{2}$ & $8.3 \times 10^{3}$ & 41 \\
\hline Photocatalysis & ethanol & 0.5 wt. $\% \mathrm{Pt} / \mathrm{TiO}_{2}$ & $3.75 \times 10^{3}$ & 38 \\
\hline Photocatalysis & ethanol & $\begin{array}{c}\mathrm{P} t / \mathrm{TiO}_{2} \\
\text { (nanocrystalline titania films) }\end{array}$ & $2.6 \times 10^{4}$ & 36 \\
\hline Photocatalysis & glucose & 1.0 wt. $\% \mathrm{Pt} / \mathrm{TiO}_{2}$ & $5.7 \times 10^{3}$ & 26 \\
\hline Photocatalysis & glucose & 0.3 wt. $\% \mathrm{Rh} / \mathrm{TiO}_{2}$ & $1.4 \times 10^{3}$ & 39 \\
\hline Photocatalysis & glucose & 0.2 wt. $\% \mathrm{NiO} / \mathrm{NaTaO}_{3}$ & $1.4 \times 10^{4}$ & 42 \\
\hline Enzymatic hydrolysis & glucose & 13 enzymes & $7 \times 10^{2}$ & 43 \\
\hline Aqueous-phase reforming & biomass derived hydrocarbons & 3.0 wt. $\%$ Pt/ $/ \mathrm{Al}_{2} \mathrm{O}_{3}$ & $\begin{array}{c}3-40 \times 10^{3} \\
\left(230-270^{\circ} \mathrm{C} \text { and } 27-54 \text { bar }\right)\end{array}$ & 44 \\
\hline
\end{tabular}

The results also demonstrated that the reaction proceeds with intermediate production of methanol and acetic acid, indicating the existence of parallel reaction pathways. It may be suggested that glycerol undergoes dehydrogenation steps on the metal surface to yield $\mathrm{H}_{2}$ and adsorbed intermediates, and that this is followed by cleavage of $\mathrm{C}-\mathrm{C}$ bonds and desorption of smaller molecules such as methanol and acetic acid. These compounds, and also fragments adsorbed on the photocatalyst surface, are subsequently oxidized by photogenerated oxidants toward $\mathrm{CO}_{2}$.

Table 1 shows the maximum hydrogen evolution rates obtained by photoreforming using a solar light-simulating source (UV light) from different biomass derivatives and photocatalysts. These rates are significantly higher than those obtained from the enzymatic hydrolysis of glucose $\left(7 \times 10^{2} \mu \mathrm{mol} \mathrm{g}^{-1} \mathrm{~h}^{-1}\right),{ }^{43}$ and are comparable to those obtained from the aqueous-phase reforming of biomassderived hydrocarbons $\left(3-40 \times 10^{3} \mu \mathrm{mol} \mathrm{g}_{\mathrm{cat}}{ }^{-1} \mathrm{~h}^{-1}\right)$ at elevated temperatures $\left(230-270{ }^{\circ} \mathrm{C}\right.$ ) and high pressures (27-54 bar), in which a catalyst with a much higher Pt load ( $\left.3 \% \mathrm{Pt} / \mathrm{Al}_{2} \mathrm{O}_{3}\right)$ was used. ${ }^{44}$

The main researches into hydrogen production by photoinduced reforming of biomass derivatives have focused on the $\mathrm{TiO}_{2}$ photocatalyst. However, the major drawback of $\mathrm{TiO}_{2}$ is its inability to utilize the visible light due to its wide band gap at $3.2 \mathrm{eV}$, which corresponds to a wavelength in the UV region. Sunlight is known to contain only about $3 \%$ of UV light. So far, research efforts have attempted mainly to extend the photosensitivity of semiconductor photocatalysts toward the visible light region in order to fully harvest solar energy, since it accounts for approximately $43 \%$ of the incoming solar energy spectrum. Currently, the biggest challenge in this field is the discovery of a photocatalyst that is able to drive the photoinduced reformation of biomass derivatives under visible light irradiation.

\section{Conclusions}

Hydrogen is an energy carrier and not an energy source; it is not readily available in nature but must derive from renewable energy sources. The earth's main source of renewable energy is the sun. Thus, the photocatalytic reforming of aqueous solutions of biomass could be an interesting and innovative route to produce hydrogen in ambient conditions. Recent researches have demonstrated that this process is suitable for application; however, these researches focus on the $\mathrm{TiO}_{2}$ photocatalyst, a wide band gap semiconductor. Thus, it is necessary to develop photocatalysts that have the thermodynamic potential to drive photoinduced reforming with visible light illumination to make effective use of solar light.

\section{Acknowledgements}

The authors acknowledge the Brazilian research funding agency Conselho Nacional de Desenvolvimento Científico e Tecnológico (CNPq) for its financial support of this research.

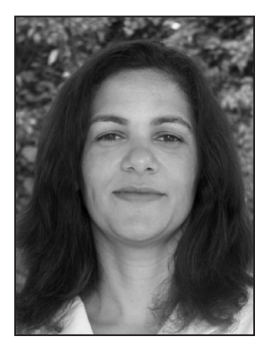

Luciana Almeida Silva received a PhD degree from the Universidade Federal da Bahia (UFBA) in 2001. She is currently an Associated Professor at the UFBA and an affiliate member of the Brazilian Academy of Sciences (2010-2014). During the academic year of 2006 she was a postdoctoral fellow in the Environmental Science and Engineering in the Division of Engineering and Applied Science at the CALTHEC (California Institute of Technology, USA), working with hybrid photochemical systems for hydrogen 
production. Her research interests are in the area of photocatalytic hydrogen production as well as the synthesis and optical properties of new semiconductor materials applied to photocatalytic reactions.

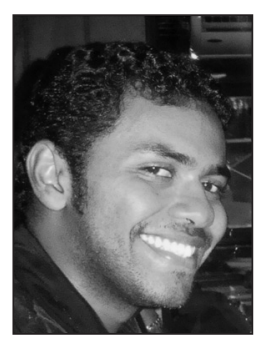

Marcos de Oliveira Melo graduated in Chemistry from the Universidade do Estado da Bahia (UNEB) in 2005 and received his MSc degree from the Universidade Federal da Bahia in 2011. He has worked with photocatalytic hydrogen production from glycerol aqueous solution under the supervision of Professor Luciana A. Silva. Currently he is a Chemist in the Department of Geochemistry of the UFBA.

\section{References}

1. Sharma, Y. C.; Singh, B.; Upadhyay, S. N.; Fuel 2008, 87, 2355.

2. Pinto, A. C.; Guarieiro, L. L. N.; Rezende, M. J. C.; Ribeiro, N. M.; Torres, E. A.; Lopes, W. A.; Pereira, P. A. P.; de Andrade, J. B.; J. Braz. Chem. Soc. 2005, 16, 1313.

3. Xuan, J.; Leung, M. K. H.; Leung, D. Y. C.; Ni, M.; Renew. Sust. Energy Rev. 2009, 13, 1301.

4. Adhikari, S.; Fernando, S. D.; Haryanto, A.; Energy Convers. Manage. 2009, 50, 2600.

5. Grimes, C. A.; Varghese, O. K.; Ranjan, S.; Light, Water, Hydrogen The Solar Generation of Hydrogen by Water Photoelectrolysis, Springer: New York, 2008.

6. Sánchez, E. A.; D’Angelo, M. A.; Comelli, R. A.; Int. J. Hydrogen Energy 2010, 35, 5902.

7. Hashaikeh, R.; Butler, I. S.; Kozinski, J. A.; Energy Fuels 2006, 20, 2743.

8. Authayanun, S.; Arpornwichanop, A.; Paengjuntuek, W.; Assabumrungrat S.; Int. J. Hydrogen Energy 2010, 35, 6617.

9. Wena, G.; Xu, Y.; Ma, H.; Xu, Z.; Tian, Z.; Int. J. Hydrogen Energy 2008, 33, 6657.

10. Marshall, A. T.; Haverkamp, R. G.; Int. J. Hydrogen Energy 2008, 33, 4649 .

11. Sabourin-Provost, G.; Hallenbeck, P. C.; Bioresour. Technol. 2009, 100, 3513.

12. Byrd, A. J.; Pant, K. K.; Gupta, R. B.; Fuel 2008, 87, 2956.

13. Adhikari S.; Fernando S.; Gwaltney, S. R; To, S. D. F.; Bricka, R. M.; Steele, P. H.; Haryanto, A.; Int. J. Hydrogen Energy 2007, 32, 2875.

14. Hoffmann, M. R.; Martin, S. T.; Choi, W.; Bahnemann, D. W.; Chem. Rev. 1995, 95, 69.

15. Wang, C.; Pagel, R.; Dohrmann, J. K.; Bahnemann, D. W.; $C$. R. Chimie 2006, 9, 761.
16. Bard, A. J.; J. Photochem. 1979, 10, 59.

17. Nozik, A. J.; J. Phys. Chem. 1996, 100, 13061.

18. Grätzel, M.; Nature 2001, 414, 338.

19. Maeda, K.; Domen, K.; J. Phys. Chem. C 2007, 111, 7851.

20. Kudo, A.; Int. J. Hydrogen Energy 2006, 31, 197.

21. Matsuoka, M.; Kitano, M.; Takeuchi, M.; Tsujimaru, K.; Anpo, M.; Thomas, J. M.; Catal. Today 2007, 122, 51.

22. Fujishima, A.; Honda, K.; Nature 1972, 238, 37.

23. Fujishima, A.; Zhang, X.; Tryk, D. A.; Int. J. Hydrogen Energy 2007, 32, 2664.

24. Kudo, A.; Miseki, Y.; Chem. Soc. Rev. 2009, 38, 253.

25. Chand, S.; Bala, S.; Physica B (Amsterdam, Neth.) 2007, 390, 179.

26. Fu, X.; Long, J.; Wang, X.; Leung, D. Y. C.; Ding, Z.; Wu, L.; Zhang, Z.; Li, Z.; Fu, X.; Int. J. Hydrogen Energy 2008, 33, 6484.

27. Antoniadou, M.; Kondarides, D. I.; Labou, D.; Neophytides, S.; Lianos, P.; Sol. Energy Mater. Sol. Cells 2010, 94, 592.

28. Bahnemann, D.; Sol. Energy 2004, 77, 445.

29. Zhao, J.; Yang, X. D.; Building Environ. 2003, 38, 645.

30. Canela, M. C.; Jardim, W. F.; Environ. Technol. 2008, $29,673$.

31. Peralta-Zamora, P., Espósito, E., Reyes, J.; Duran, N.; Quim. Nova 1997, 20, 186.

32. Silva, L. A.; Ryu, S. Y.; Choi, J.; Choi, W.; Hoffmann, M. R.; J. Phys. Chem. C 2008, 112, 12069.

33. Mourão, H. A. J. L.; Mendonça, V. R.; Malagutti, A. R.; Ribeiro, C.; Quim. Nova 2009, 32, 2181.

34. Patsoura, A.; Kondarides, D. I.; Verykios, X. E.; Appl. Catal., B 2006, 64, 171

35. Patsoura, A, Kondarides D. I.; Verykios, X. E.; Catal. Today 2007, 124, 94

36. Strataki, N.; Bekiari, V.; Kondarides, D. I.; Lianos, P.; Appl. Catal., B 2007, 77, 184.

37. Kawai, T.; Sakata, T.; Chem. Lett. 1981, 10, 81.

38. Kondarides, D. I.; Daskalaki, V. M.; Patsoura, A.; Verykios, X. E.; Catal. Lett. 2008, 122, 26.

39. Wu, G. P.; Chen, T.; Zhou, G. H.; Zong, X.; Li, C.; Sci. China Ser. B-Chem. 2008, 51, 97.

40. Daskalaki, V. M.; Kondarides, D. I.; Catal. Today 2009, 144, 75.

41. Luo, N.; Jiang, Z.; Shi, H.; Cao, F.; Xiao, T.; Edward, P. P.; Int. J. Hydrogen Energy 2009, 34, 125.

42. Fu, X.; Wang, X.; Leung, D. Y. C.; Xue, W.; Ding, Z.; Huang, H.; Fu, X.; Catal. Commun. 2010, 12, 184.

43. Zhang, Y.-H. P.; Evans, B. R.; Mielenz, J. R.; Hopkins, R. C.; Adams, M. W. W.; PLOS ONE 2007, 2, 456.

44. Davda, R. R.; Shabaker, J. W.; Huber, G. W.; Cortright, R. D.; Dumesic, J. A.; Appl. Catal. B 2005, 56, 171.

Submitted: February 4, 2011

Published online: April 28, 2011 